\title{
Komentarz - riwaroksaban 2,5 mg + ASA w wytycznych ESC 2019
}

\author{
The commentary - rivaroxaban $2.5 \mathrm{mg}+$ ASA in ESC 2019 guidelines
}

\section{prof. dr hab. n. med. Zbigniew Kalarus}

Oddział Kliniczny Kardiologii Katedry Kardiologii, Wrodzonych Wad Serca i Elektroterapii Śląskiego Uniwersytetu Medycznego, Śląskie Centrum Chorób Serca w Zabrzu

Podczas tegorocznego kongresu Europejskiego Towarzystwa Kardiologicznego (ESC, European Society of (ardiology) w Paryżu zaprezentowano nowe wytyczne ESC dotyczące diagnostyki i leczenia przewlekłych zespołów wieńcowych (CCS, chronic coronary syndromes). Zmiana nazewnictwa ze stabilnej choroby wieńcowej na przewlekłe zespoły wieńcowe odzwierciedla fakt, że pacjenci z miażdżycą tętnic wieńcowych są stale obciążeni istotnie wyższym ryzykiem ostrych incydentów sercowo-naczyniowych w porównaniu z populacją ogólną. Ryzyko to stanowi continuum - prawidłowa kontrola czynników ryzyka, właściwe zmiany stylu życia, optymalna farmakoterapia oraz kompletna rewaskularyzacja znacząco je obniżają, natomiast niepełna i niewłaściwa realizacja zasad prewencji wtórnej znamiennie to ryzyko zwiększają. W aktualnym dokumencie zdecydowanie podkreślono, że leczenie przeciwzakrzepowe jest kluczową częścią profilaktyki wtórnej u pacjentów z CCS. W obecnych rekomendacjach nakazuje się rozważyć (klasa zaleceń IIa, poziom wiarygodności A) dołączenie do kwasu acetylosalicylowego (ASA, acetylsalicylic acid) drugiego leku przeciwzakrzepowego, w ramach długoterminowej prewencji wtórnej, u pa- cjentów z rytmem zatokowym, obciążonych wysokim ryzykiem zdarzeń niedokrwiennych (pacjenci z rozsianą/wielonaczyniową chorobą wieńcową oraz obarczeni $\geq 1$ z następujących czynników: cukrzyca, ponowny zawał serca, choroba tętnic obwodowych, przewlekła choroba nerek z szacowanym współczynnikiem filtracji kłębuszkowej [eGFR, estimated glomerular filtration rate] $15-59 \mathrm{ml} /$ /min/1,73 m²) i jednocześnie bez wysokiego ryzyka krwawienia. Ponadto taką formę leczenia można rozważyć (klasa zaleceń IIb, poziom wiarygodności A) u chorych cechujących się umiarkowanym ryzykiem zdarzeń niedokrwiennych (pacjenci obarczeni $\geq 1$ spośród wymienionych czynników ryzyka: rozsiana/wielonaczyniowa choroba wieńcowa, cukrzyca, niewydolność serca, ponowny zawał serca, choroba tętnic obwodowych, przewlekła choroba nerek z eGFR $15-59 \mathrm{ml} / \mathrm{min} / 1,73 \mathrm{~m}^{2}$ ) i bez wysokiego ryzyka powikłań krwotocznych. Składową tej terapii, poza ASA w dawce 75-100 mg/dobę, może być inhibitor $\mathrm{P}_{2} \mathrm{Y}_{12}$ (klopidogrel, prasugrel, tikagrelor) lub riwaroksaban (w dawce $2 \times 2,5 \mathrm{mg}$ ), który jest jedynym lekiem z grupy leków przeciwkrzepliwych niebędących antagonistami witaminy K (NOAC, non-vitamin K antagonist oral anticoagulants) zare- 
jestrowanym i rekomendowanym w tym wskazaniu. Tak silna pozycja riwaroksabanu $\mathrm{w}$ aktualnych wytycznych ESC jest odzwierciedleniem wyników badania COMPASS (Rivaroxaban for the prevention of major cardiovascular events in coronary or peripheral artery disease), $\mathrm{w}$ którym stosowanie połączenia ASA $\mathrm{z}$ riwaroksabanem w dawce 2 razy $2,5 \mathrm{mg}$ u pacjentów z CCS prowadziło do względnego obniżenia ryzyka: udaru mózgu - o 42\% ( $<<0,001)$, zawału serca-o $14 \%(p<0,15)$, zgonu sercowo-naczyniowego - o 22\% ( $p<0,01)$ oraz niekorzystnych zdarzeń sercowo-naczyniowych (MACE, major adverse cardiac events $)$ - o 24\% ( $\mathrm{p}<0,001)$. Ponadto należy podkreślić, że spośród rekomendowanych leków jedynie stosowanie riwaroksabanu łącznie z ASA było związane ze znamienną statystycznie, 18-procentową redukcją ryzyka zgonu z dowolnej przyczyny $\mathrm{u}$ chorych $\mathrm{z}$ CCS. Skojarzona terapia ASA z riwaroksabanem (w dawce $2 \times 2,5 \mathrm{mg}$ ) wiązała się $\mathrm{z}$ istotnie wyższą częstością poważnych krwawień $(3,1 \%$ vs.
1,9\%; $\mathrm{p}<0,05)$ niż monoterapia ASA, jednak odsetek krwotoków wewnątrzczaszkowych oraz krwawień zakończonych zgonem nie uległ istotnej zmianie. W badaniu COMPASS wykazano, co warto zaznaczyć, że szczególnie wysokie korzyści ze stosowania riwaroksabanu w małej dawce odnoszą chorzy na cukrzycę (zmniejszenie częstości MACE o 28\%) oraz pacjenci z chorobą tętnic obwodowych (redukcja występowania MACE aż o 33\%).

W świetle nowych wytycznych ESC stosowanie skojarzonego leczenia za pomocą ASA i riwaroksabanu w małej dawce w ramach długoterminowej prewencji wtórnej może się przyczynić do istotnego ograniczenia występowania niekorzystnych zdarzeń sercowo-naczyniowych u pacjentów z grupy wysokiego/umiarkowanego ryzyka zdarzeń niedokrwiennych. Poza najważniejszym wymiarem czysto medycznym, należy także zwrócić uwagę na oczywiste korzyści społeczno-ekonomiczne wynikające z poprawy rokowania w tej populacji. 